\title{
Influence of the ruminal N-balance on rumen metabolism
}

\author{
A. Riemeier ${ }^{1}$, P. Lebzien and G. Flachowsky \\ Institute of Animal Nutrition, Federal Agricultural Research Centre (FAL) \\ Bundesallee 50, D - 38116 Braunschweig, Germany
}

\section{ABSTRACT}

Fistulated dairy cows were used to investigate the influence of the ruminal N-balance (RNB) on protein metabolism in the rumen. Animals were fed a ration of maize silage and concentrates. RNB amounted to $-0.6 \mathrm{~g} / \mathrm{MJ} \mathrm{ME}$ in the basis ration. The other 3 rations were adjusted to RNB-values of $-0.3,0$ and $0.3 \mathrm{~g} / \mathrm{MJ} \mathrm{ME}$ by urea supplements.

The RNB increase resulted in higher $\mathrm{NH}_{3}-\mathrm{N}$ concentrations in the rumen fluid and the duodenal digesta and urea concentrations in the milk and blood. The efficiency of microbial protein (MP) synthesis was the same, $\mathrm{g}$ MP/MJ ME was significant lower with RNB -0.6 g/MJ ME as compared to RNB 0 . The group with the lowest RNB showed the highest level of feed protein degradation and the lowest organic matter fermentation.

KEY WORDS: cow, rumen fermentation, ruminal N-balance

\section{INTRODUCTION}

The German Protein Evalution System for dairy cows (GfE 2001) considers the protein requirement of the animal (utilizable crude protein at the duodenum $=$ $\mathrm{uCP}$ ) and the N-requirement of the rumen microbes (ruminal N-balance $=\mathrm{RNB}$ ). RNB was calculated by differene from $\mathrm{CP}$ intake minus microbial and undegraded feed protein at the duodenum divided by 6.25 .

The recommendation on RNB has to consider 2 different goals:

1. A N-shortage in the rumen (RNB to low) has to be avoided to ensure a maximal fermentation rate and a sufficient microbial protein synthesis.

2. A surplus of degradable N (RNB too high) would lead to an uneconomic protein utilization and an increased $\mathrm{N}$-excretion.

\footnotetext{
${ }^{1}$ Corresponding author: e-mail: andrea.riemeier@fal.de
} 
This raises the question on the lowest N-quantity in the rumen, which does not negatively affect the rumen metabolism.

The Committee for Requirement Standards of the Society of Nutrition Physiology (GfE, 2001) points out that $20 \%$ of the synthesized microbial protein $(10.1 \mathrm{~g} / \mathrm{MJ} \mathrm{ME})$ might be from recycled $\mathrm{N}$, with the consequence that a negative RNB of max. $-0.3 \mathrm{~g} / \mathrm{MJ}$ ME could be accepted.

The aim of the present investigations was to reconsider this value with 5-7 fistulated cows. This was performed by using RNB-values below (-0.6 g/MJ $\mathrm{ME}$ ) or over ( 0 and $+0.3 \mathrm{~g} / \mathrm{MJ} \mathrm{ME})$ the value of $-0.3 \mathrm{~g} / \mathrm{MJ}$ ME. Parameters for evaluation of rumen fermentation, microbial protein synthesis, amount of $\mathrm{uCP}$ and $\mathrm{N}$-excretion were studied.

\section{MATERIAL AND METHODS}

The dairy cows, which were involved in this experiment, were fitted with cannulae in the dorsal part of the rumen and at the proximal duodenum. Average liveweight of the animals and average milk yield were $562 \mathrm{~kg}( \pm 50)$ and $25.5 \mathrm{~kg}$ $\mathrm{FCM}( \pm 7.9)$. The animals were fed a constant daily ration consisting of $7.3 \mathrm{~kg}$ dry matter of maize silage and $7.3 \mathrm{~kg}$ dry matter of concentrate. Only the RNB of the ration was increased from $-0.6 \mathrm{~g} / \mathrm{MJ} \mathrm{ME}$ to $-0.3,0$ or $+0.3 \mathrm{~g} / \mathrm{MJ} \mathrm{ME}$, respectively, by supplements of different urea amounts to the concentrates.

The experiments comprised 4 periods, in which the animals were fed in exchange one of the 4 concentrate types. Animals were adapted to the ration over two weeks. In week 3 rumen fluid samples were taken. In week 4 samples from the duodenal chyme were taken in $2 \mathrm{~h}$ intervals over 5 days. To estimate the digesta flux $\mathrm{Cr}_{2} \mathrm{O}_{3}$ was used as marker (Rohr et al., 1979).

The portion of microbial $\mathrm{N}$ on NAN in the duodenal chyme was analysed applying the NIRS-technique (Lebzien and Paul, 1997).

\section{RESULTS AND DISCUSSION}

Ammonia-N concentration in the rumen fluid increased from 1.1 to 20.3 $\mathrm{mmol} / \mathrm{l}$ and in the duodenal chyme from 2.1 to $8.1 \mathrm{mmol} / 1$ due to higher RNBvalues (Figure 1). The $\mathrm{NH}_{3}$-concentration in group -0.6 which amounted to 1.1 $\mathrm{mmol} / \mathrm{l}$ was found to be remarkably lower than 4-6 mmol/l, which Piatkowski et al. (1990) postulated to be necessary for an optimal rumen fermentation.

The urea concentration in milk increased from 1.1 to $5.4 \mathrm{mmol} / 1$ and in the serum from 1.0 to $7.9 \mathrm{mmol} / 1$ due to higher RNB-values (Figure 2).

The RNB did not show significant effects on efficiency of protein synthesis (g/kg FOM) but related to ME intake microbial protein synthesis in group -0.6 was significantly lower than in group 0 (Table 1 ). 


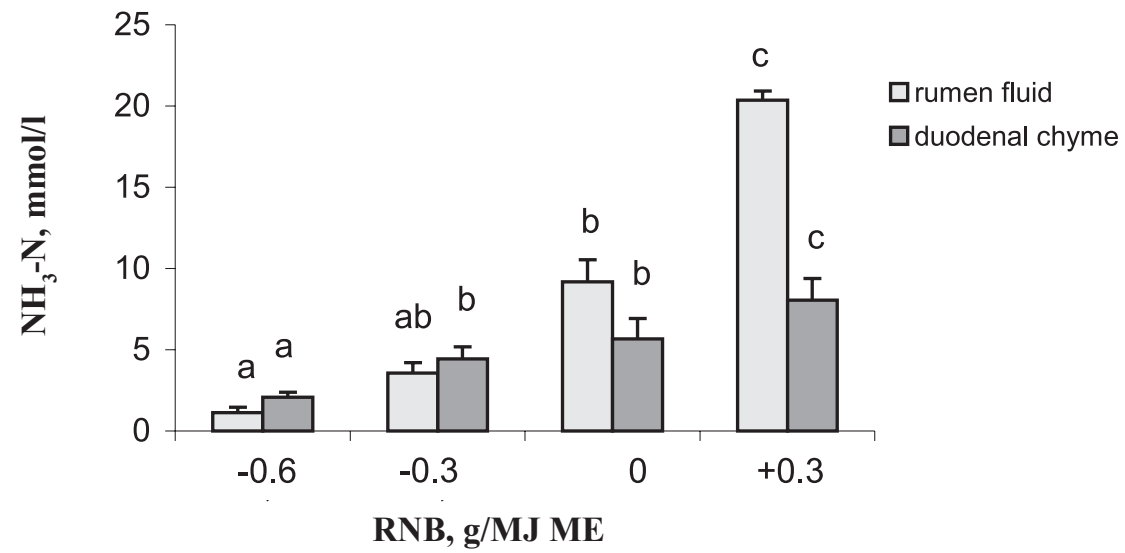

Figure 1. Average $\mathrm{NH}_{3}-\mathrm{N}$-concentration in the rumen $3 \mathrm{~h}$ after start of feeding and in the duodenal chyme as affected at different RNBs $(c>b>a, P \leq 0.05)$

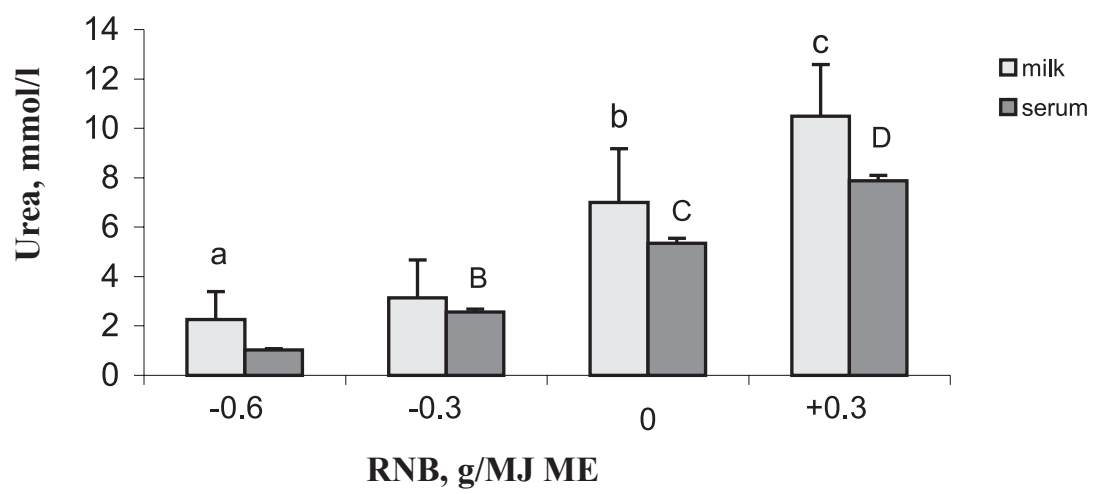

Figure 2. Average urea concentration in the milk and blood serum at different $\mathrm{RNBs}(\mathrm{a}<\mathrm{b}<\mathrm{c}, \mathrm{P} \leq 0.05$ and $\mathrm{A}<\mathrm{B}<\mathrm{C}<\mathrm{D}, \mathrm{P} \leq 0.01)$

The quantity of fermented organic matter ( $\mathrm{kg}$ FOM) was reduced, when RNB was lowered. Beside this protein degradation increased and the quantity of UDP decreased. Due to the reduced MP and UDP quantity in the RNB-group -0.6 the uCP-quantity was lower than in the other three groups, but only significantly to the group 0 (Table 1). 
Table 1. Quantity of fermented organic matter and flux of the N-fractions passing the duodenum

\begin{tabular}{|c|c|c|c|c|}
\hline $\mathrm{RNB}, \mathrm{g} / \mathrm{MJ} \mathrm{ME}$ & $\begin{array}{l}-0.6 \\
\mathrm{n}=7\end{array}$ & $\begin{array}{l}-0.3 \\
\mathrm{n}=5\end{array}$ & $\begin{array}{c}0 \\
\mathrm{n}=7\end{array}$ & $\begin{array}{r}+0.3 \\
\mathrm{n}=7\end{array}$ \\
\hline \multicolumn{5}{|l|}{ Fermented organic matter (FOM) } \\
\hline $\mathrm{kg} / \mathrm{d}$ & $9.3^{b} \pm 0.6$ & $9.4^{\mathrm{ab}} \pm 0.7$ & $10.1^{\mathrm{a}} \pm 0.5$ & $9.9^{\mathrm{ab}} \pm 0.5$ \\
\hline$\%$ of organic matter intake & $65.6^{\mathrm{b}} \pm 3.0$ & $66.8^{\mathrm{ab}} \pm 5.2$ & $70.0^{\mathrm{a}} \pm 1.9$ & $68.2^{\mathrm{ab}} \pm 3.2$ \\
\hline $\begin{array}{l}\text { Utilizable crude protein (uCP) } \\
\mathrm{g} / \mathrm{d}^{1}\end{array}$ & $1686^{\mathrm{b}} \pm 215$ & $1792^{\mathrm{ab}} \pm 254$ & $2084^{a} \pm 249$ & $1911^{\mathrm{ab}} \pm 219$ \\
\hline $\begin{array}{l}\text { Undegraded feed protein (UDP) } \\
\qquad \mathrm{g} / \mathrm{d}\end{array}$ & $350^{\mathrm{b}} \pm 82$ & $442^{\mathrm{ab}} \pm 106$ & $532^{\mathrm{a}} \pm 70$ & $470^{\mathrm{a}} \pm 60$ \\
\hline \multicolumn{5}{|l|}{ Microbial protein (MP) } \\
\hline $\mathrm{g} / \mathrm{d}$ & $1336^{\mathrm{b}} \pm 143$ & $1350^{\mathrm{ab}} \pm 150$ & $1552^{\mathrm{a}} \pm 184$ & $1441^{\mathrm{ab}} \pm 174$ \\
\hline $\mathrm{g} / \mathrm{MJ} \mathrm{ME}$ & $7.66^{\mathrm{b}} \pm 0.78$ & $7.84^{\mathrm{ab}} \pm 0.9$ & $8.83^{\mathrm{a}} \pm 0.82$ & $8.25^{\mathrm{ab}} \pm 0.9$ \\
\hline $\mathrm{g} / \mathrm{kg} \mathrm{FOM}$ & $143 \pm 13$ & $143 \pm 8$ & $153 \pm 14$ & $146 \pm 15$ \\
\hline
\end{tabular}

${ }^{1} \mathrm{uCP}=\mathrm{MP}+\mathrm{UDP} ; \mathrm{a}>\mathrm{b}(\mathrm{P} \leq 0.05)$

The amount of $\mathrm{N}$ in urine increased from 67 to $262 \mathrm{~g} / \mathrm{d}$ and in faeces from 89 to $104 \mathrm{~g} / \mathrm{d}$ due to higher RNB-values (Table 2).

Table 2. N-amounts in urine and faeces at different RNBs

\begin{tabular}{llccc}
\hline RNB, g/MJ ME & -0.6 & -0.3 & 0 & +0.3 \\
\hline N-urine, g/d & $67 \pm 0$ & $81 \pm 4$ & $153 \pm 38$ & $262 \pm 115$ \\
N-faeces, g/d & $89 \pm 10$ & $96 \pm 11$ & $110 \pm 12$ & $104 \pm 11$ \\
\hline
\end{tabular}

The results on $\mathrm{N}$-excretion with urine and faeces were not treated statistically, because they are based on $\mathrm{Cr}_{2} \mathrm{O}_{3}$ - and creatine-concentrations in a few spot samples from only some of the animals. Effects on the $\mathrm{pH}$-value in the rumen and the volatile fatty acid concentration were not detected.

From the results it can be concluded, that significantly negative effects of a $\mathrm{N}$ shortage on rumen fermentation occur, when RNB was lower than $-0.3 \mathrm{~g} / \mathrm{MJ} \mathrm{ME}$.

\section{REFERENCES}

GfE, 2001. Empfehlung zur Energie- und Nährstoffversorgung der Milchkühe und Aufzuchtrinder. DLG Verlag

Lebzien P., Paul C., 1997. Use of near-infrared reflecteance spectroscopy for the estimation of the microbial portion of non-ammonia-nitrogen in the duodenum of dairy cows. Anim. Feed Sci. Tech. 68, 225-233

Piatkowski B., Gürtler H., Voigt J., 1990. Grundzüge der Wiederkäuerernährung. Gustav Fischer Verlag, Jena

Rohr K., Brandt M., Castrillo O., Lebzien P., Assmus G., 1979. Der Einfluss eines teilweisen Ersatzes von Futterprotein durch Harnstoff auf den Stickstoff- und Aminosäurenfluss am Duodenum. Landbauforsch. Völkenrode 29, 32-40 